\title{
Morphological Study of Myoneural Interaction between the Levator Labii Superioris Muscle and its Motor Nerve in Rats
}

\author{
Estudio Morfológico de la Interacción Mioneural entre el \\ Músculo Elevador del Labio Superior y su Nervio Motor en Ratas
}

"Carina Guimarães de Souza Melo; *André Luis Shinohara; **Jesus Carlos Andreo \& **Antonio de Castro Rodrigues

MELO, C. G. S.; SHINOHARA, A. L.; ANDREO, J. C. \& RODRIGUES, A. C. Morphological study of myoneural interaction between the levator labii superioris muscle and its motor nerve in rats. Int. J. Morphol., 27(3):627-634, 2009.

SUMMARY: The progress of science in search of new techniques of the nerve regeneration and the functional repair in reinnervated muscle has been the target of many researchers around the world. Consequently, nerves and muscles in different body segments asked for more enlightenment of their morphology, their interrelation with other anatomic structures and their peculiarities. One of the most significant areas that need deeper studies is the region of the head and neck, since they are often affected by important pathologies. In order to offer the researcher's community a morphological myoneural interaction model, this study elected the levator labii superioris muscle and its motor nerve, the buccal branch of the facial nerve (VII pair) not only for its special characteristics, but also its value on the facial expression. The rat was chosen for this investigation for being easy to obtain, to keep, to manipulate and to compare this experiment with many others studies previously published. The techniques used were Mesoscopic (dissection), histoenzymologic and morphometric ones.In the results the muscle proved to have a predominance of fast twich fibers (FG and FOG) and superficial location, with a proximal bone and a distal cutaneous insertion. Its motor nerve, the buccal branch of the facial nerve (VII pair), breaks through the muscle belly into its deep face, and comprised a heterogeneous group of myelinic nerve fibers disposed in a regular form in all fascicle. Near the motor point, the nerve showed to be composed of two fascicles with different sizes. Due to the small nerve dimensions, the nerve fibers have a smaller diameter if compared to the motor nerve of pectineus muscle of the cat. Further studies with neural tracers have already had a start in order to provide more information about the distribution and the architecture of these fibers.

KEY WORDS: Nerve; Morphology; Morphometry; Levator labii superioris muscle; Rat.

\section{INTRODUCTION}

Peripheral nerves and skeletal striated muscles are often the target of traumatic lesions (Millesi, 2000). According to a study performed in USA, each year, 50 thousand people suffer traumatic lesions in peripheral nerves (Evans, 2001). The severity of the nerve damage may vary, to the extent of the traumatic lesion. The nerve injuries can be classified in five categories (Sunderland, 1978), from a simple compression to a total nerve transection.

In the last 25 years, surgical techniques to recover nerves and muscles have disclosed significant advances, and have reached an optimal technical refinement (Rodrigues \& Schmalbruch, 1995; Lundborg, 2000; Millesi; Strauch, 2000; Meek \& Coert, 2002; Dvali \& Mackinnon, 2003). This fact led to many researchers to detail factors, mechanisms and techniques, that allow the restoration of these structures (Crisci \& Ferreira, 2002).

In spite of many improvements on this area of investigation, a complete recovery of all sensory functions in an adult patient is still rare after nerve repair (Lundborg). This fact motivated us to offer the scientific community, a morphological myoneural interaction model, with morphological aspects, like the formation, the estimated number of nerve and muscle fibers, the area of these fibers, the types of muscle fibers, and other aspects. This model intends to offer the researchers a paradigm of muscle-nerve interaction, with specific patterns, accessible to professionals,

\footnotetext{
* Post-Graduation student, FOB/USP, Bauru, São Paulo, Brazil.

**Department of Biological Sciences, FOB/USP, Bauru, São Paulo, Brazil.
} 
which can be used in many different experimental procedures on this research line.

The region of the head and neck is one of the most significant areas that need deeper studies because it is often affected by important pathologies. Studies had investigated the structure of the facial nerve and its injuries, which can be caused by traumatic lesions, iatrogenic conditions or oncology principles. The complications, which are extremely unpleasant, and have serious consequences, not rarely, come to interfere in the patient's facial identity. Therefore, attempts to reestablish the function of the facial nerve, have long been published in the literature (Raldi et al., 2002). Thus, we decided to choose as the aim of this study the levator labii superioris muscle and its motor nerve, a branch of the facial nerve (VII pair of cranial nerves), not only for its special characteristics, but also for its value on the facial expression. The embryological origin of this muscle makes this study a challenge, considering that in branchiomeric muscles it is more difficult to standardize the technique to identify the different types of muscle fibers, than to do it in somitic muscles.

The levator labii superioris muscle is reported in many studies of macroscopic dissection, especially its intimate relation with the other facial muscles (Ferreira et al., 1997; Spiegel \& De Rosa, 2005), and with adjacent structures, like the ductal of parotid gland. Likewise, the branches of facial nerve are anatomic correlated, making it essential to know its real location, distinction of the different branches, and the verification of anastomosis between them (Freitas et al., 1994). The course and the distribution of these branches are relevant to the treatment of facial palsy, and to the protection of facial nerve during surgery (Liu et al., 2007). The buccal branch of facial nerve is described as the responsible for the innervation of other facial muscles, such as the procerus muscle (Hwang et al., 2006) and corrugator supercilii muscle (Caminer et al., 2006).

The reported muscle is so integrated into the facial expression that its electromyographic activity can be measured when a person is induced to imagine and to act according to some situations, or to perform some physical common activities (Cacioppo et al., 1984). This means that there is a relationship between self-report of emotion and physiological expression of emotion (Vrana, 1993).

The importance of this muscle is undeniable in facial reconstructive surgeries, where a flap of a mimic muscle can be used to repair the loss of facial tissue (Ferreira et al.). The region of the mid-face represents a challenging area for surgeons who work in reconstructive and aesthetic procedures, due to its details, patterns and anatomic variations of the muscular anatomy, specifically in the nasolabial area (Pessa et al., 1998). This area also presents many correlated structures with an important connection to the soft tissue.

Finally, based on the information observed in the respective literature, the aim of this study is to evaluate morphologically the constitution of levator labii superioris muscle, especially the morphometry of its fibers and the frequency of occurrence of the different types of fibers. It also aims at evaluating by using morphological criteria, the nerve to the mentioned muscle, its origin and course from de facial nerve and the morphometry of its myelinic fibers. In summary, to offer to the scientific community a model of myoneural interaction, with specific patterns for the development of other studies involving nerve regeneration and functional repair in branchiomeric muscles.

\section{MATERIAL AND METHOD}

Our work was previously approved by the Research Ethics Committee Involving Animals (FOB/USP/Bauru).

Animals used. Fifteen male Wistar rats, with an average weight of $300 \mathrm{~g}$ and 90 days old, coming from the Central Vivarium of FOB /USP / Bauru, were utilized. The animals were kept in the Bioterium, in groups of 5 per cage, having access to water and food ad libitum, for three months. The lighting schedule in the housing room was 12 hours light and 12 hours dark, per day.

This study was divided into four phases: dissection, histochemistry, histoenzimology and morphometry.

Dissection. In the first phase five animals were sacrificed with an overdose $(70 \mathrm{mg} / \mathrm{Kg})$ of the anesthesic pentobarbital (hypnol), intraperitoneally. Next, tricotomy of the right hemiface was performed with a razor blade. The dissections were carried out with the help of the surgical microscope DF Vasconcelos, and microsurgery instruments, which fosterd a better tissue manipulation, since the facial structures of the rat presented small dimensions. The dissection sessions were performed with the purpose to evaluate the dimension and the distribution of the levator labii superioris muscle and its motor branch in the facial composition, and the correlated anatomic structures. At this point, we noted that the buccal branch of facial nerve was responsable for the innervation in the mentioned muscle.

Histochemistry. In the second phase, five other animals were taken, weighted, and sacrificed. The tricotomy of the right hemiface was performed. The surgical microscope was used 
to collect the muscle and the motor nerve (a branch of VII pair) in each animal. The muscles were weighed with an electronic scale (Table I). Samples were obtained from the medial portion of the muscles, and from distal segments of the nerves. The harvested slices were left in room temperature for 15 minutes, as recommended by Khan (1977). Then, the samples were fixed in a formol solution (10\%). After the fixation time, the samples were washed in tap water for 12 hours and transferred to a container with alcohol $70 \%$. After that, a number of sections of $8 \mu \mathrm{m}$ thickness were obtained from the muscular samples and submitted to hematoxylineosin (HE) staining, in order to analyse the general morphology of the fibers in the muscle and the nerve.

Table I. The average body weight (BW) and the weight of the levator labii superioris muscle (MW).

\begin{tabular}{ccc}
\hline Animal & $\boldsymbol{B W}(\boldsymbol{g})$ & $\boldsymbol{M W}(\boldsymbol{g})$ \\
\hline $\mathbf{1}$ & 346 & 0.026 \\
$\mathbf{2}$ & 415 & 0.042 \\
$\mathbf{3}$ & 324 & 0.038 \\
$\mathbf{4}$ & 331 & 0.032 \\
$\mathbf{5}$ & 300 & 0.036 \\
$\overline{\mathrm{X}}$ & 343.2 & 0.035 \\
$\mathbf{S}$ & 43.44 & 0.005 \\
\hline
\end{tabular}

Histoenzymology. In the third phase, five animals were sacrificed, and the entire muscle was removed. After that, a sample of the harvested muscle was collected using a scalpel blade that help perform a cut without lacerate the fibers. These samples were covered with neutral talcum and frozen in n-hexane, cooled to $-70^{\circ} \mathrm{C}$, in liquid nitrogen for 2 minutes using the method of Chayen et al. (1969). The samples were kept in a container filled with liquid nitrogen until the moment of being submitted to histochemical reactions. These frozen samples were cut into $10 \mu \mathrm{m}$ in thickness in serial cross-sections in microtome cryostat at $-20^{\circ} \mathrm{C}$. The sections were affixed in preheated slides at $36^{\circ} \mathrm{C}$, and maintained in room temperature for 45 minutes, following the method of Eversole \& Standish (1970). The sections were submitted to m-ATPase (with acid pre-incubation) and for NADH-TR reactions. Based on these enzymatics activities, the myofibers were classified as FG, FOG and SO, according to Peter et al. (1972).

Morphometry. Using the virtual resources of a digital image system coupled to an OLYMPUS B202 microscope, the images of the slides were stained by $\mathrm{HE}$ and by the enzymatic activity of NADH-TR (metabolic characteristics) and $\mathrm{m}$-ATPase (contractile characteristics), and then captureted to perform the morphometrical analysis.

\section{RESULTS}

The average body weight of the rats and the weight of the levator labii superioris muscle were $343.2 \mathrm{~g}$ and 0.035 $\mathrm{g}$, respectively (Table I). The estimated total number of muscle fibers in the right hemiface was 244.6 fibers (Table II).

Table II. The estimated total number of the muscle fibers (TF), the average value of muscle fiber area $(n=100)$ (MFA) and the total area of the muscle (TA).

\begin{tabular}{cccc}
\hline Animal & $\boldsymbol{T F}$ & $\boldsymbol{M F A}\left(\boldsymbol{\mu m ^ { 2 } )}\right.$ & $\boldsymbol{T A}\left(\mathbf{m m}^{2}\right)$ \\
\hline $\mathbf{1}$ & 269 & 9.29 & 2.25 \\
$\mathbf{2}$ & 305 & 8.24 & 2.23 \\
$\mathbf{3}$ & 154 & 9.16 & 1.62 \\
$\mathbf{4}$ & 238 & 9.07 & 2.42 \\
$\mathbf{5}$ & 257 & 9.85 & 2.76 \\
$\overline{\mathrm{X}}$ & 244.6 & 9.12 & 2.26 \\
$\mathbf{S}$ & 56.23 & 0.58 & 0.41 \\
\hline
\end{tabular}

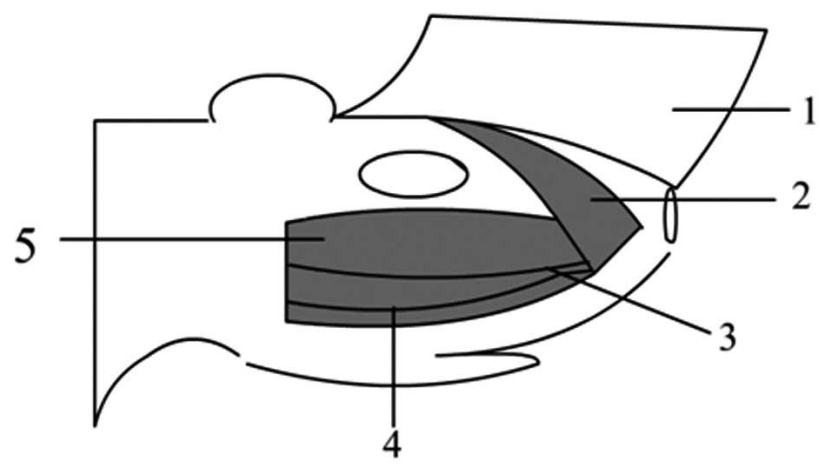

Fig. 1. Draw illustrating the levator labii superioris muscle and its motor nerve. 1. Skin; 2. Levator labii superioris muscle; 3. Buccal branch of facial nerve; 4. Marginal mandibular branch of the facial nerve; 5 . Masseter muscle.

The nerve branch responsible for innervation of the levator labii superioris muscle, is unique in most of its extension, measuring approximately $0.5 \mathrm{~cm}$ in length and $0.5 \mathrm{~mm}$ in diameter. This branch starts from the buccal branch of facial nerve, and penetrates the mentioned muscle in its distal third, on the deep face, similar to humans. The branch origin can be noticed after the buccal branch of facial nerve crosses the anterior margin of the masseter muscle (Fig. 1). Throughout its course, the nerve is involved by the loose connective tissue, with many adipocytes. The histological cuts of the studied nerve were obtained from anterior region just before its penetration into the muscle, showing the presence of two branches, one of larger diameter. Each nerve fascicle is formed by a large number of myelinic fibers with heterogeneous diameters. 
Among the nerve fibers, a moderate concentration of collagen fiber was observed. Externally, all fascicle were wrapped by a connective tissue, the perineurium (Fig. 2). In every animal, 200 myelinic fibers were evaluated in the nerve branch; the diameters of the fibers and thickness of myelin sheath were measured (Table III).

Table III. The diameter of myelinic fibers (DMF) and the thickness of myelin sheath (TMS) $(\mathrm{n}=100)$.

\begin{tabular}{ccc}
\hline Animal & DMF $(\boldsymbol{\mu m})$ & TMS $(\boldsymbol{\mu m})$ \\
\hline $\mathbf{1}$ & 0.09 & 0.024 \\
$\mathbf{2}$ & 0.11 & 0.031 \\
$\mathbf{3}$ & 0.08 & 0.028 \\
$\mathbf{4}$ & 0.10 & 0.026 \\
$\mathbf{5}$ & 0.16 & 0.032 \\
\hline$\overline{\mathrm{X}}$ & 0.108 & 0.032 \\
$\mathbf{S}$ & 0.031 & 0.003 \\
\hline
\end{tabular}

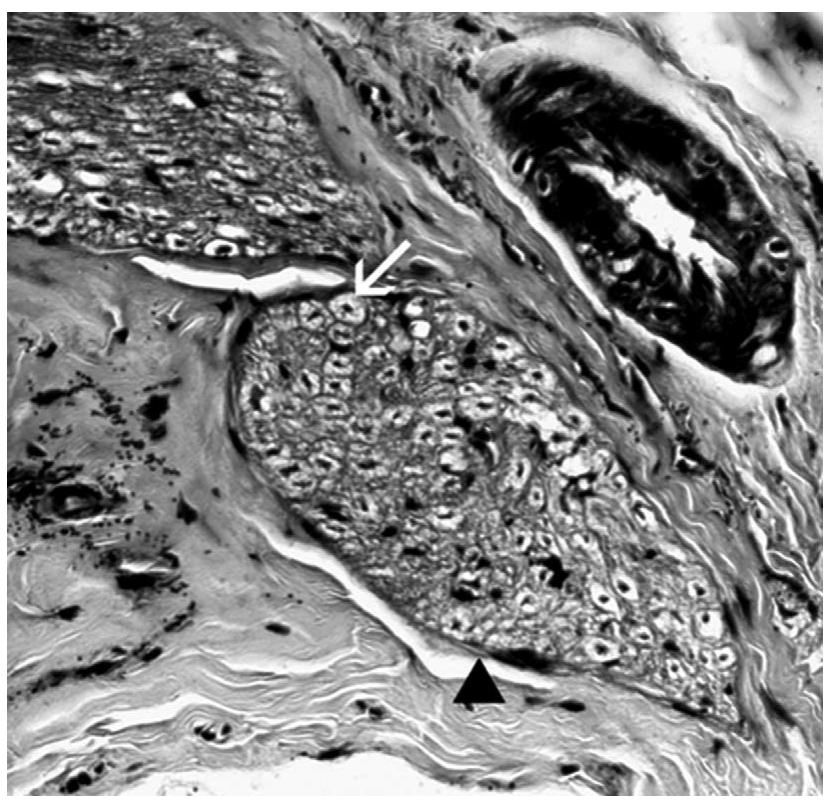

Fig. 2. Photomicrography: the motor nerve to levator labii superioris muscle in rat. Two fascicles can be noted, and myelinic nerve fibers sectioned transversely. Perineurium (arrow head) e myelinated fiber (arrow), HE. 200X.

Using the routine coloration techniques (HE), the muscle presented a normal pattern, with a preserved morphology. The muscle fibers presented a polygonal profile, with a fascicle arrangement, and dyed nucleus eccentrically located (Fig. 3A).

According to histochemical tests reactivity, the levator labii superioris muscle is consisted of a mosaic distribution of three types of muscle fibers: 1- SO (slow-oxidative) intense reaction and smaller area ; 2- FOG (fast-oxidativeglycolitic): moderate reaction and intermediate area, and 3FG (fast-glycolitic): weak reaction and larger area (Fig. 3).

The average value of a muscle fiber area was 9.12 $\mu \mathrm{m}^{2}$, while the average value of the total muscle area was $2.26 \mathrm{~mm}^{2}$ (Table II).

\section{DISCUSSION}

The goal of this descriptive study was to evaluate the levator labii superioris muscle and its motor nerve, and to offer the cientific comunity a model of myoneural interaction, based on specific morphologic parameters.

The nerve to levator labii superioris muscle of the rat is unique; it starts from the buccal branch of facial nerve (VII pair of cranial nerve), and it is correlated with the ductal of parotid gland, as it occurs in humans (Liu et al.), and with the zygomatic branch of the facial nerve (Erbil et al., 2007; Saylam et al., 2006). The knowledge of these data provides surgeons with anatomic basis for future surgical strategies (Woltmann et al., 2006), avoiding lesions in the facial nerve region, wich is often prone to injuries that require interventions (Guntinas-Lichius et al., 2007). Important data can also be obtained through clinical examination, using electromyography method (Wolf et al., 2006; Armstrong et al., 2007), as many facial muscles present more than one motor unity. Thus, each modality of physiotherapy used in the treatment of facial palsy (Shafshak, 2006), or even the manual stimulation (Guntinas-Lichius et al.), can be better applied, by using the information about the quantity and location of the motor points. It was possible to observe that the motor branch penetrated the muscle rat in its deep face, obeying the frequent disposition of most myoneural interaction.

Although not addressed into depth, we observed that the branch nerve presented two fascicles close to the muscle, one having a larger area if compared to the other one. The arrangement of myelinic fibers inside the nerve fascicles was homogeneous, with no concentration in different regions. Similar results were observed by Rodrigues et al. (1994) about the nerve branch to the pectineus muscle of the cat (Felis domestica). To analyse the diameters in the myelinic fibers, measurements were taken from their smaller diameter, so as to avoid errors with overestimated values (Mayhew \& Sharma, 1984; Dubowitz, 1985). The diameter measurements of the buccal branch of facial nerve, in 200 fibers of each animal, presented values varying between $0.007 \mathrm{~mm}$ and $0.041 \mathrm{~mm}$, 


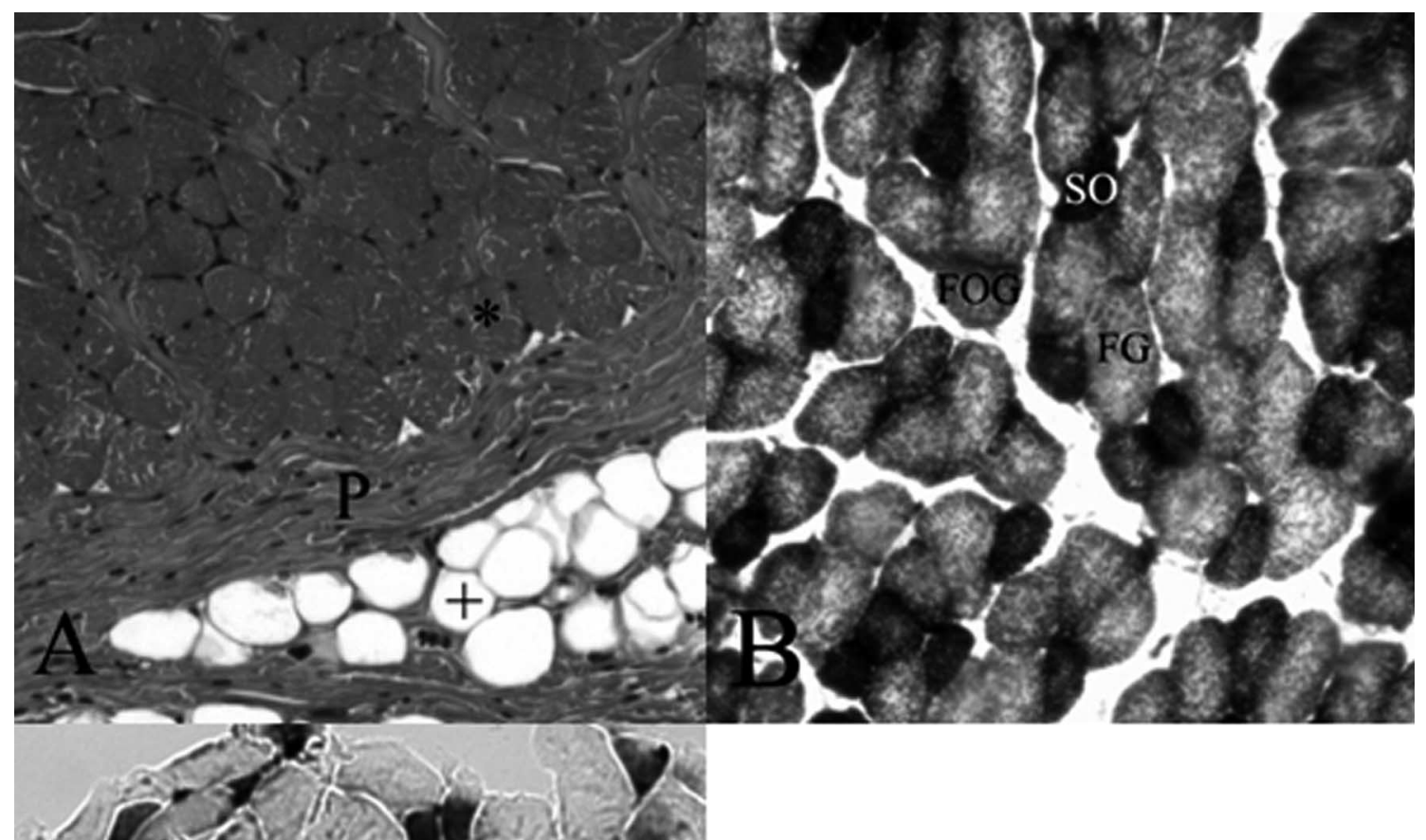

Fig. 3. Photomicrography of fibers in levator labii superioris muscle in rat. A- region near to the fascicle margin, polygonal fibers $(*)$, perimysium (p) and adipocytes (+), HE 100X. B - muscle submitted to NADH-TR reaction, the different types of fibers ( $\mathrm{SO}$, FOG e FG), based on metabolic characteristics, 100X. C-muscle submitted to $\mathrm{m}$-ATPase reaction, the different types of fibers ( $\mathrm{SO}, \mathrm{FOG}$ e FG) based on contractile characteristics, 100X.

different from the results found by Schmalbruch (1986), in which the values were between $0.42 \mathrm{~mm}$ and $7.65 \mathrm{~mm}$ in the tibial and femoral nerve in the rat. This observation is probably related with the frequency of the different fiber types in the levator labii superioris muscle, that has a predominance of white fibers, that is fast twitch fibers (Table IV).

The nerve fibers with larger diameter are classified as alpha fibers, and they innervate the motor units of fast twitch fibers (Asbury \& Johnson, 1968; Mastaglia \& Walton, 1984). Our estimate results, of the total number of fibers present in the levator labii superioris muscle, $60.2 \%$ were FG, $26.6 \%$ were FOG and $13.2 \%$ were SO. The final results were similar to the values found for Rodrigues et al., in the pectineus muscle of the cat.
Table IV. Percentage of the different types of muscle fibers in levator labii superioris muscle in rats.

\begin{tabular}{cccc}
\hline Animal & $\boldsymbol{F G}(\boldsymbol{\%})$ & $\boldsymbol{F O G}(\%)$ & $\boldsymbol{S O}(\%)$ \\
\hline $\mathbf{1}$ & 59 & 23 & 18 \\
$\mathbf{2}$ & 61 & 26 & 13 \\
$\mathbf{3}$ & 65 & 24 & 11 \\
$\mathbf{4}$ & 57 & 34 & 9 \\
$\mathbf{5}$ & 59 & 26 & 15 \\
\hline $\bar{X}$ & 60.2 & 26.6 & 13.2 \\
$\mathbf{S}$ & 3.03 & 4.34 & 3.5 \\
\hline
\end{tabular}

The diameter of nerve fibers is variable in the course of any nerve (Boyd \& Davey, 1968). In the dorsal root, the 
diameter is nearly three times greater than close to the motor point (Gilliat, 1966). Hence, we can expect that the nerve fibers near to the motor point in the muscle, have smaller diameters than close to the facial trunk. According to previous studies, the nerve fibers with larger diameter have thicker myelin sheath (Asbury \& Johnson; Machado, 1983); and the thickness of nerve fiber is intimately related to nerve conduction speed, and making these measurements important. Considering all these information, we can infer that the levator labii superioris muscle has a predominance of motor units of fast twitch, indicating its intense activity related to the vibrissae movement and the tactile sensory in the rat (Faria et al., 2006). In other animals, like the cat for example, each $\mu \mathrm{m}$ in thickness corresponds to a velocity of $6 \mathrm{~m} / \mathrm{s}$ in a nerve fiber conduction (McPhedran et al., 1965). There is a certain disagreement about the number of myelinated nerve fibers and the function of the nerve, which can be afferent or efferent fibers. Thus, to Rexed \& Therman (1948) $60 \%$ of myelinated nerve fibers in a determinated nerve are motor fibers. On the contrary, to Boyd \& Davey (1968) this value is aproximetely 50\%. Roughly, we don't really believe that general values can be applied to all nerves, but each nerve answers to its functional demand, and even that there is a pattern of electrical activation in a muscle
(English, 1984). Further studies with neural tracers, using derived from peroxidase could be more enlightening.

The nerve to the levator labii superioris muscle presented its fibers intertwined with the fibers of the infraorbital nerve, which is a sensitive nerve related to vibrissae movement in the rat (Veronesi et al., 2006) and prone to injuries during surgical procedures (Hu et al., 2007).

In summary, the purpose of this study was to contribute to a better knowledge of the morphology of the levator labii superioris muscle and its motor nerve, along with other research lines that evaluate branchiomeric muscle and cranial nerve. Other projects are being done with the main objective of describing the nerve fibers in the studied muscle and correlate it to its functions. A detailed knowledge of microscopic anatomy of nerves in rats, helps to obtain data which are essential for experimental studies of induced neuropathies. Besides that it provides a better understanding of human pathologies, and the development of safer surgical techniques.

ACKNOWLEDGEMENTS. We would like to thank FAPESP for the financial grant.

MELO, C. G. S.; SHINOHARA, A. L.; ANDREO, J. C. \& RODRIGUES, A. C. Estudio morfológico de la interacción mioneural entre el músculo elevador del labio superior y su nervio motor en ratas. Int. J. Morphol., 27(3):627-634, 2009.

RESUMEN: El progreso de la ciencia en busca de nuevas técnicas para la regeneración neural y la recuperación funcional de los músculos reinervados, ha atraído el interés de muchos investigadores en todo el mundo. En consecuencia, los músculos y los nervios merecen más aclaraciones sobre su morfología, relaciones anatómicas y particularidades. Entre las áreas que merecen estudios más profundos y detallados, está la región de cabeza y cuello, que es a menudo afectada por enfermedades graves. Con el propósito de ofrecer a la comunidad científica un modelo morfológico de interacción mioneural, se eligió el músculo elevador del labio superior y su nervio motor, la rama bucal del nervio facial (VII par craneal), por sus especiales características y su importancia en la expresión facial. En esta investigación se optó por la rata, por las facilidades de obtención, de manejo y para comparar los datos obtenidos con estudios previos. Se utilizaron técnicas mesoscópicas de disección, histoenzimológicas y morfométricas. Los resultados mostraron un músculo con predominio de fibras de contracción rápida (FG y FOG), ubicación superficial, inserción proximal ósea e inserción distal en la piel. Su nervio motor, la rama bucal del nervio facial, ingresa en el vientre muscular en la cara profunda, y está compuesto por un grupo heterogéneo de fibras nerviosas mielínicas dispuestas de forma regular por todo el fascículo nervioso cerca del punto motor. El nervio es formado por dos fascículos de diferentes tamaños. Debido a las pequeñas dimensiones en la rata, el diámetro de las fibras nerviosas presenta valores reducidos, en comparación con el nervio motor del músculo pectíneo en el gato, por ejemplo. Los datos aportados podrán ser usados como referencia en estudios de regeneración en nervios y músculos. Otros estudios con marcadores neuronales se iniciaron para aclarar la distribución y la estructura de las fibras mencionadas.

PALABRAS CLAVE: Nervio; Morfología; Morfometría; Músculo elevador del labio superior; Ratas.

\section{REFERENCES}

Armstrong, J. E.; Hutchinson, I.; Laing, D. G. \& Jinks, A. L. Facial electromyography: responses of children to odor and taste stimuli. Chem. Senses, 32(6):611-21, 2007.

Asbury, A. K. \& Johnson, P. C. Pathology of peripheral nerve. London, W. B. Saunders Company, 1968.
Boyd, I. A. \& Davey, M. R. Composition of peripheral nerve. Edinburgh, Livengstone, 1968.

Cacioppo, J. T.; Petty, R. E. \& Marshall-Goodell, B. Electromyographic specificity during simple physical and attitudinal tasks: location and topographical features 
of integrated EMG responses. Biol. Psychol., 18(2):85$121,1984$.

Caminer, D. M.; Newman, M. I. \& Boyd, J. B. Angular nerve: new insights on innervation of the corrugator supercilii and procerus muscles. J. Plast. Reconstr. Aesthetic. Surg., 59(4):366-72, 2006.

Chayen, J.; Bitensky, L.; Butcher, R.G. \& Poulter, L.W. A guide to practical histochemistry. Edinburgh, London, Oliver \& Boyd, 1969.

Crisci, A. R. \& Ferreira, L. F. Low-intensity pulsed ultrasound acdelerates the regeneration of the sciatic nerve after neurotomy in rats. Ultrasound Med. \& Biol., 28(10):1335-41, 2002.

Dvali, L. \& Mackinnon, S. Nerve repair, grafting, and nerve transfers. Clin. Plast. Surg., 30(2):203-21, 2003.

Dubowitz, V. Muscle biopsy. 2a. Ed. London, Bailliere Tindall, 1985. p.403.

English, A. W. An electromyographic analysis of compartments in cat lateral gastrocnemius muscle during unrestrained locomotion. J. Neurophysiol., 52(1):11425,1984 .

Erbil, K. M.; Uz, A.; Hayran, M.; Mas, N.; Senan, S. \& Tuncel, M. The relationship of the parotid duct to the buccal and zygomatic branches of the facial nerve; an anatomical study with parameters of clinical interest. Folia Morphol., 66(2):109-14, 2007.

Evans, G. R. Peripheral nerve injury: A review and approach to tissue engineered constructs. Anat. Rec., 263(4):396404, 2001.

Eversole, L. S. \& Standish, S. M. Histochemical demonstration of muscle fibre types. J. Histochem. Cytochem., 18:591-3, 1970.

Faria, S. D. ; Testa, J. R. G.; Borin, A. \& Toledo, R. N. Standardization of techniques used in facial nerve section and facial movement evaluation in rats. Rev. Bras. Otorrinolaringol., 72(3):341-7, 2006.

Ferreira, L. M.; Minami, E.; Pereira, M. D.; Chohfi, L. M. \& Andrews J. M. Anatomical study of the levator labii superioris muscle. Rev. Assoc. Med. Bras., 43(3):185-8, 1997.

Freitas, C. A. F.; Fukuyama, E. E.; Hojaij, F. C.; Cernea, C.
R.; Nishio, S. \& Ferraz, A. R. Anatomic study of the mandibular ramus of the facial nerve. Rev. Bras. Cir. Cabeca Pescoco, 18(2/3):81-3, 1994.

Gilliat, R.G. Axon branching in motor nerves. In: Amdrew, B. L. (Ed.). Control and innervation of skeletal muscle. Edinburgh, Livingston Ltd., 1966. p.532.

Guntinas-Lichius, O.; Hundeshagen, G.; Paling, T.; Streppel, M.; Grosheva, M.; Irintchev, A.; Skouras, E.; Alvanou, A.; Angelova, S. K.; Kuerten, S.; Sinis, N.; Dunlop, S. A. \& Angelov, D. N. Manual stimulation of facial muscles improves functional recovery after hypoglossalfacial anastomosis and interpositional nerve grafting of the facial nerve in adult rats. Neurobiol. Dis., 28(1):10112, 2007.

Hu, K. S.; Kwak, J.; Koh, K. S.; Abe, S.; Fontaine, C. \& Kim, H. J. Topographic distribution area of the infraorbital nerve. Surg. Radiol. Anat., 29(5):383-8, 2007.

Hwang, K.; Jin, S.; Park, J. H. \& Chung, I. H. Innervation of the procerus muscle. J. Craniofac. Surg., 17(3):484-6, 2006.

Khan, M. A. The histoenzimology of striated muscle fibers: an overview. Cell Mol. Biol., 22:383-93, 1977.

Liu A. T.; Jiang, H.; Zhao, Y. Z.; Yu, D. Z.; Dang, R. S.; Zhang, Y. F. \& Zhang, J. L. Anatomy of buccal and marginal mandibular branches of facial nerve and its clinical significance. Zhonghua Zheng Xing Wai Ke Za Zhi, 23(5):434-7, 2007.

Lundborg, G. A 25-year perspective of peripheral nerve surgery: Evolving neuroscientific concepts and clinical significance. J. Hand Surg. [Am]., 25(3):391-414, 2000.

Machado, A. B. M. Neuroanatomia funcional. Rio de Janeiro, Livraria Atheneu, 1983.

Mastaglia, F. L. \& Walton, J. Skeletal muscle pathology. Edinburgh, New York, Churchill Livingston, 1984.

Mayhew, T. M. \& Sharma, A. K. Sampling schemes for estimating nerve fiber size. Methods for nerve trunks of mixed fascicularity. J. Anat., 139:45-58, 1984.

McPhedran, A. M.; Wuerker, R. B. \& Henneman, E. Properties of motor units in a homogeneus red muscle (soleus) of the cat. J. Neurophysiol., 28:71-84, 1965.

Meek, M. F.\& Coert, J. H. Clinical use of nerve conduits in 
peripheral-nerve repair: Review of the literature. $J$. Reconstr. Microsurg., 18(2):97-109, 2002.

Millesi, H. Techniques for nerve grafting. Hand Clin., $16(1): 73-91,2000$.

Pessa, J. E.; Zadoo, V. P.; Adrian, E. K. Jr.; Yuan, C. H. \& Avdelotte, J. \& Garza, J. R. Variability of the midfacial muscles: analysis of 50 hemifacial cadáver disections. Plast. Reconstr. Surg., 102(6):1888-93, 1998.

Peter, J. B.; Barnard, R. J.; Edgerto, V. R.; Gillespie, C. A. \& Stempel, K. E. Metabolic profiles of three fiber types of skeletal muscle in guinea pigs and rabbits. Biochemistry, 11:2627-33, 1972.

Raldi, F. V.; Filho, W. N. \& Santos, L. M. Comparative study between conventional surgery and carbon dioxide laser $\left(\mathrm{CO}_{2}\right)$ in the orientation of the reparation of the facial nerve: Histological study in rats. Rev. Fac. Odontol. Bauru; 10(2):105-11, 2002.

Rexed, B. \& Therman, P. Calibre spectra of motor and sensory nerve fibres to flexor and extensor muscles. $J$. Neurophysiol., 11:131-9, 1948.

Rodrigues, A. C.; Dal Pai, V.; Mota, D. L. ; Paisilva, M. D. \& Padovani, C. R. Contribuição ao estudo das Unidades Motoras do músculo pectíneo do gato (Felis domestica). Rev. bras. ciênc. morfol., 11(2):149-58, 1994.

Rodrigues, A. C. \& Schmalbruch, H. Satellite cells and myonuclei in long-term denervated rat muscles. Anat. Rec., 243(4):430-7, 1995.

Saylam, C.; Ucerler, H.; Orhan, M. \& Ozek, C. Anatomic landmarks of the buccal branches of the facial nerve. Surg. Radiol. Anat., 28(5):462-7, 2006.

Schmalbruch, H. Fiber composition of the rat sciatic nerve. Anat. Rec., 215:71-81, 1986.

Shafshak, T. F. The treatment of facial palsy from the point of view of physical and rehabilitation medicine. Eura. Medicophys., 42(1):41-7, 2006.

Spiegel, J. H. \& De Rosa, J. The anatomical relationship between the orbicularis oculi muscle and the levator labii superioris and zygomaticus muscle complexes. Plast. Reconstr. Surg., 116(7):1937-42, 2005.

Strauch, B. Use of nerve conduits in peripheral nerve repair. Hand Clin., 16(1):123-30, 2000.
Sunderland, S. Nerves and nerve injuries. New York, Churchill Livingstone, 1978.

Veronesi, C.; Maggiolini, E. \& Franchi, G. Postnatal development of vibrissae motor output following neonatal infraorbital nerve manipulation. Exp. Neurol., 200(2):332-42, 2006.

Vrana, S. R. The psychophysiology of disgust: differentiating negative emotional contexts with facial EMG. Psychophysiology, 30(3):279-86, 1993.

Wolf, K.; Mass, R.; Kiefer, F.; Wiedemann, K. \& Naber, D. Characterization of the facial expression of emotions in schizophrenia patients: Preliminary findings with a new electromyography method. Can. J. Psychiatry., 51(6):335-41, 2006.

Woltmann, M.; Faveri, R. \& Sgrott, E. A. Anatomosurgical study of the marginal mandibular branch of the facial nerve for submandibular surgical approach. Braz. Dent. J., 17(1):71-4, 2006.

Correspondence to:

Prof. Dr. Antonio de Castro Rodrigues

Departamento de Ciências Biológicas

FOB/USP

Av. Octávio Pinheiro Brisola, 9-75, Aeroporto

CEP17012-901

Bauru - São Paulo

BRASIL

Telefone: +55 (14) 3235-8226

Fax: +55 (14) 3223-5525

Email: acastro@fob.usp.br

Received: 27-08-2008

Accepted: 28-05-2009 